\title{
PRESS RELEASE
}

\section{An immovable property tax proposal in Groatia: some open issues}

\author{
MARINA KESNER-ŠKREB, MSC, Institute of Public Finance, Zagreb
}

\begin{abstract}
The Groatian Ministry of Finance and The Tax Administration on November 22, 2012 presented a new Immovable Property Tax Bill, opening up a public debate on the bill to be signed into law on April I, 2013. 'This long-announced tax has sparked off stormy debate, and even aroused sharp political controversies.
\end{abstract}

Recently, the media have come up with dramatic conjectures about the immovable property tax burden on citizens. However, many people were relieved after the formal presentation of the tax, as its burden is not likely to be that heavy after all. A I.5 percent uniform tax rate will be applied to $70 \%$ of the immovable property's fiscal value and there will be abundant tax relief, so that the effective tax rates are going to be relatively low. It is anticipated that the tax burden for the majority of citizens will be equal to the sum of the current utility fees and the second home tax (both to be removed with the introduction of the new tax). The authors of the law deserve commendation for showing consideration for the really grave economic situation in the country, and, consequently, refraining from any heavier immovable property taxation. High tax amounts would place additional burden on citizens' incomes and lead to the outflow of private income to the local governments' budgets instead to personal consumption. And, the Croatian government sector is already oversized and the economic recession too deep. However, despite the commendable relatively low tax rates on immovable property, the presented tax proposal still raises some questions.

\begin{tabular}{|c|c|}
\hline Question & Answer \\
\hline Who pays the tax? & Domestic and foreign natural and legal persons using the immovable property. \\
\hline Who is exempt from tax? & $\begin{array}{l}\text { I. Certain institutions and certain types of immovable property (I2 immovable } \\
\text { property types) } \\
\text { 2. Pension beneficiaries, unemployed persons, homeland war veterans, disabled } \\
\text { persons - for I immovable property item, but exclusively subject to social } \\
\text { welfare programmes regulated by the ULSG* decisions }\end{array}$ \\
\hline What is the subject of tax? & $\begin{array}{l}\text { Built-up immovable property (according to the construction status) } \\
\text { Building land, excluding agricultural land }\end{array}$ \\
\hline What is the tax rate? & I. $5 \%$ \\
\hline What constitutes the tax base? & $70 \%$ of the fiscal value (reduced by relief). The fiscal value is assessed at a 5-year interval \\
\hline Types of tax relief? & 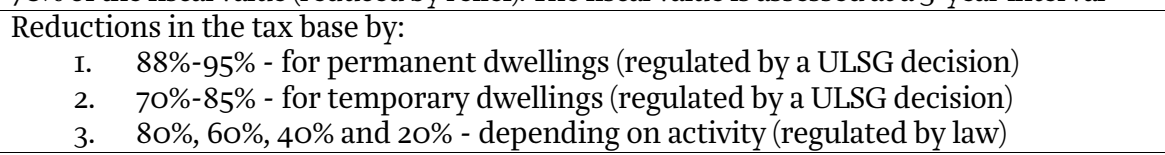 \\
\hline Who gets the tax revenues? & $\begin{array}{l}\text { Local budgets } \\
\text { Exceptionally, tax on immovable property owned by cities and municipalities - state budget }\end{array}$ \\
\hline When is the tax due? & Annual tax payable in monthly increments \\
\hline When does it become effective? & April I, 2OI3; the first tax rulings are expected on September I, 2013. \\
\hline
\end{tabular}

${ }^{\mathrm{I}}$ Government of the RC. News and Announcements. Predstavljen prijedlog Zakona o porezu na nekretnine: Stopa I,5\% uz brojne porezne olakšice (in Croatian only). November 22, 2012. 
I. Revenues and administrative costs. The presentation of the new law proposal did not include projections of the revenues from the tax to be collected by local budgets, nor its administrative costs to be borne by government administration. Such simulations should be a usual basis for making decisions on any change in taxes, and even more so in the case of introducing an entirely new taxation form. First estimates and the presentation itself suggest that the funds raised will be relatively modest, while the administrative cost of tax collection will be sizeable, at least in the first year. And here is why:

- $\quad$ Revenues. The Bill provides for numerous types of relief and reductions. Reduced tax will thus be paid on immovable property used for permanent and temporary dwelling, as well as that used for performing some specific activities. Fully exempt from tax will be selected institutions (for example the Red Cross), and the users of 12 types of immovable property (airport land area, cultural and public goods, religious buildings, etc.). The list contains a total of 25 types of immovable property that are either completely exempt from tax or subject to tax on a reduced base. In addition, under the welfare programmes of the units of local selfgovernment, some citizens will be exempt from tax for a single immovable property item. Given all the exempt immovable property items and taxpayers, it is questionable what will remain of the taxable base and what the collected revenue will be in the first place. It should be particularly emphasized that a large number of tax exemptions has always and everywhere led to massive tax evasion. Taxpayers become highly imaginative in finding numerous legal, but sometimes also illegal ways to outmanoeuvre tax authorities. Therefore, theory has always emphasized that a better tax is the one applied to an as broad as possible tax base at a unified rate and with minimum exemptions.

- Administrative costs ${ }^{2}$. Another element to be assessed is the administrative cost of tax collection. The main characteristic of the new tax is that, unlike with the current utility fees and second home tax where the tax base is the surface area in square meters, this tax is charged on an ad valorem tax base. It is exactly this element that mainly determines the administrative tax collection costs, which will definitely be high, notably in the first year of tax application. The Tax Administration must set up a so-called fiscal register, which will store the assessed values of all immovable property items. The register should be completed by the end of March 2013, which is an extremely short period for such a large exercise. More specifically, the fiscal values of all immovable property items in Croatia should be assessed based on the average market price (already existing in the Tax Administration's databases of purchased and sold property), year of construction, location, development phase and construction quality. This is a comprehensive exercise which will involve, in addition to the Tax Administration, the State Geodetic Administration and units of local self-government (ULSGs). In some areas, it will be necessary to take an on-the-spot assessment to establish the actual value of immovable property. It is expected that this enormous job, which includes value assessment of as many as I4.5 million cadastral units, will require strong IT support in terms of both hardware and advanced software programmes. ${ }^{3}$ All this takes time and requires substantial financial resources. Moreover, it puts an additional strain on the Tax Administration, as it has to dispose with a large number of well-trained tax officers, with good knowledge of the tax and the ability to assess the entitlements to relief. They will also be required to contact taxpayers directly in order to establish whether a particular immovable property item is used permanently or only temporarily, or whether it is completely out of use.

\footnotetext{
${ }^{2}$ Substantial research has been conducted at the Institute of Public Finance on administrative costs of taxation. For more details, see: http://www.ijf.hr/eng/publications/.

${ }^{3}$ HRT, 2012. Radio na zahtjev - U mreži Prvog. November 23, 2012 (a radio show on immovable property tax, with Nada ČavlovićSmiljanec, Head of the Tax Administration, as a guest (translator's note).
} 
2. Implementation stages of the immovable property tax. According to the presentation, the primary aim of the immovable property tax introduction is to ease the tax burden on labour. This should be introduced gradually, in three stages. These stages were presented by the Ministry of Finance and Tax Administration as follows:

- Stage I. - Shifting a portion of the tax burden from labour to immovable property = introducing an immovable property tax and abolishing utility fees and second home tax.

- Stage II. - Further development of the immovable property taxation system, through decentralisation and improvement in the services of ULSGs, reflected in a higher quality of life.

- Stage III. - Ultimate reduction or abolishment of excessive taxes and/or other quasi-taxes. Specifically mentioned is the abolishment of the surtax on personal income tax and monument annuity.

The three stages are very vaguely defined. For example, what exactly does the formulation "further development of the immovable property taxation system" under Stage II imply, i.e. in what direction will the development of the taxation system actually go? Similar ambiguity exists about the time schedule of this gradual process, i.e. in which year one stage begins and another ends. In which year can we expect the accomplishment of the main goal of introducing the immovable property tax (cutting the labour costs)? According to the presentation, this should not be achieved until Stage III, after the surtax on personal income tax has been lifted.

However, it is not quite clear when the new tax will generate enough funds to lift the surtax on personal income tax, which is a constituent part of the labour costs. In other words, when can the announced relief of the tax burden on labour really come true? In 20II, the ULSGs collected about HRK one billion in surtax revenues and about HRK 2 billion in utility fees and second home tax revenues ${ }^{4}$. At Stage I, it is only expected that utility fees and the second home tax will be replaced by immovable property tax, i.e. revenues from property tax are likely to be about HRK 2 billion. However, in order to create conditions for removing the surtax, the immovable property tax is obviously planned to grow further, to be able to generate another one billion kuna. Only then will it be possible to abolish the surtax, without significantly undermining local budgets. However, the presentation says nothing about when will conditions be ripe for the accomplishment of the main goal of launching the immovable property tax, i.e. reduction of labour costs.

3. Impact on local budgets and the national budget. The lifting of the utility fees and second home tax and their replacement by immovable property tax also involves uncertainties as to the budget revenues of ULSGs. For example, the amount of the tax base is uncertain: the ULSGs still have to assess the immovable property's fiscal values and determine the range of the immovable property tax relief. Taxpayers are also the Republic of Croatia, counties, cities and municipalities on their immovable property, so that they will also be obliged to pay tax at a rate of $1.5 \%$. The central budget will also be entitled to a portion of revenues from the tax, because the tax on immovable property owned by cities and municipalities will constitute the revenues of the national budget. The financial implications of all this for both local budgets and the national budget will be visible at the end of 2013 .

4. Impact on entrepreneurs' balance sheets. Immovable property tax will be payable by all entrepreneurs, subject to certain relief which depends on activity. A tax base reduction of $80 \%$ is provided for immovable property in industry and manufacturing, health care, education and non-profit organisations; 60\% for leased immovable property, construction, transportation and storage and hotels and restaurants; a 40\% reduction for trade and $20 \%$ for other activities. Of course, the amount of tax will depend on the assessed fiscal value of the immovable property used (or not used) by entrepreneurs, which is yet to be determined. Hence, the actual tax amount payable on immovable property of businesses in 2013 is still unknown. This is another unknown term in the entrepreneurs' balance sheets, and 'unknowns' are very bad for investment activity. Public utility companies are also faced with uncertainty, as they have been financed by revenues from utility fees collected by ULSGs und

${ }^{4}$ Ministry of Finance of the RC. Ostvarenje proračuna: JLP(R)S 2OIO-2OII. Zagreb: Ministry of Finance. 
5. transferred to them. The utility fees (which will soon become history) are strictly earmarked for the financing of public utility services (street lighting, public area cleaning, cemetery maintenance, etc.). This levy will now be replaced by the immovable property tax as generalpurpose revenues to be spent at the discretion of ULSGs. The question is how much of its tax revenues an ULSG will be prepared to give up to utility companies in future. It follows that there are also uncertainties about the balance sheets of the local utility companies. It would

6. therefore be better to refrain from introducing the new tax in the middle of the business year, and to announce it in advance, so that all business entities would have enough time to adjust their financial plans.

7. Questionable constitutionality. It should further be reminded that Croatia has already had tax on unused immovable property, i.e. taxes on: uncultivated arable land, undeveloped building land an unused entrepreneurial immovable property. These taxes were abolished as unconstitutional in 2007, pursuant to a Constitutional Court decision ${ }^{5}$. The Decision provides that "it is concluded that owners of entrepreneurial property or undeveloped agricultural land shall not be forced to act or proceed in a specific way (in this case: to use the aforementioned immovable property)...". What we have now is a proposal for a similar tax "penalizing" immovable property owners for not using their property, i.e. paying the full amount of tax without relief. It is reasonable to expect that the same arguments employed to remove the previous three unconstitutional taxes will be invoked in this case as well ${ }^{6}$.

As shown above, the new tax proposal leaves many issues open ${ }^{7}$. It is only to be expected that the Ministry of Finance and Tax Administration will closely consider all advantages and drawbacks of the proposed tax, hear the arguments of as many as possible interested parties in order to design a tax that will be the least distortive and in compliance with the fundamental principles of tax policy: efficiency, equity and simplicity.

\footnotetext{
${ }^{5}$ Decision of the Constitutional Court of the Republic of Croatia No. U-I-I559/2O0I. and U-I-2355/2002, of February 2I, 2007 (OG 26/O7).

${ }^{6}$ For more details, see Jelčić, ., 20I2. Najavljene promjene u oporezivanju imovine u Republici Hrvatskoj - Prijedlozi i mišljenja. Informator. Zagreb, May 30, 2012, No. 6076.

${ }^{7}$ Various aspects of immovable property taxation in Croatia and the EU are analysed in Kesner-Škreb, M., 20I2. "Much ado about nothing - three questions about immovable property taxation in Croatia”. Newsletter No. 66 and Kesner-Škreb, M., 2009. "What should one know about immovable property taxation in Croatia?” Newsletter No. 46. Zagreb: Institute of Public Finance.
} 